\title{
FINITE ELEMENT PREDICTION FOR THE INTERNAL STRESSES OF (Ti,AI)N COATINGS
}

\begin{abstract}
The general topic of this paper is the computer simulation with use of finite element method (FEM) for determining the internal stresses of selected gradient and single-layer PVD coatings deposited on the sintered tool materials, including cemented carbides, cermets and $\mathrm{Al}_{2} \mathrm{O}_{3}+$ TiC type oxide tool ceramics by cathodic arc evaporation CAE-PVD method.

Developing an appropriate model allows the prediction of properties of PVD coatings, which are also the criterion of their selection for specific items, based on the parameters of technological processes. In addition, developed model can to a large extent eliminate the need for expensive and time-consuming experimental studies for the computer simulation.

Developed models of internal stresses were performed with use of finite element method in ANSYS environment. The experimental values of stresses were calculated using the X-ray $\sin 2 \psi$ technique. The computer simulation results were compared with the experimental results. Microhardness and adhesion as well as wear range were measured to investigate the influence of stress distribution on the mechanical and functional properties of coatings.

It was stated that occurrence of compressive stresses on the surface of gradient coating has advantageous influence on their mechanical properties, especially on microhardness. Absolute value reduction of internal stresses in the connection zone in case of the gradient coatings takes profitably effects on improvement the adhesion of coatings. It can be one of the most important reasons of increase the wear resistance of gradient coatings in comparison to single-layer coatings.
\end{abstract}

Keyword: Analysing and modelling, PVD coatings, gradient coatings, internal stresses

\section{Introduction}

The finite element method is currently commonly used in such branches of science, like: mechanics, biomechanics, mechatronics, materials engineering, and thermodynamics [1-8]. All types of simulations shorten the design process and give the possibility to investigate the particular factors on the entire model. This is often impossible to achieve in real conditions or not justified economically. The finite element method makes it possible to understand the relationships among various parameters better and makes it possible to select the optimum solution. Applying of this method contains many fields of contemporary industry and also modern technologies are supported by using of computers [1-6]. MES system can be treated as one of program belonging to $\mathrm{CAD} / \mathrm{CAM} /$ CAE group, which contain complex supporting of designing tools cycle, beginning with constructing up to realization of manufacture processes [1-3].

Gradient PVD coatings can be deposited onto cutting tools made as well from the high speed steels, cemented carbides, cermets, and also from ceramic materials. In the development of new, contemporary materials the functionality is often improved by combining materials of different properties into composites $[7,8,12,13]$.

In combination with the rapid development of new coating technologies, this has led to an accelerating increase in the use of coated components. Physical vapor deposited TiN coatings are widely used for machining of a wide variety of materials. Coatings based on (Ti,Al)N as well as $\mathrm{Ti}(\mathrm{C}, \mathrm{N})$ were developed to provide better performance over titanium nitride since the incorporation of aluminum or carbon in TiN increased hardness, decreased coefficient of friction of the coatings [9]. Among wide range of PVD methods cathodic arc vapor deposition is widely used due to their ability to provide a dense and adherent thin coating at a relatively low temperature [8-10].

The aim of the paper is FEM modelling of the internal stresses of gradient and single -layer coatings (Ti,Al)N and $\mathrm{Ti}(\mathrm{C}, \mathrm{N})$ deposited on the sintered tool materials, including cemented carbides, cermets and $\mathrm{Al}_{2} \mathrm{O}_{3}+\mathrm{TiC}$ type oxide tool ceramics by cathodic arc evaporation CAE-PVD method.

\section{Methodology of research}

The tests were made on specimens of the cemented carbides, cermet and oxide tool ceramics substrates deposited with single-layer and gradient $(\mathrm{Ti}, \mathrm{Al}) \mathrm{N}$ coatings, using the cathodic arc evaporation method (CAE). The characteristics of the investigated materials are presented in Table 1.

The Ra surface roughness parameter measurements and observations of surfaces topography of the developed coatings were made on LSM 5 PASCAL confocal microscope. The Vickers microhardness was measured using the Hanemann tester. The microhardness tests were made with the load of 0.1 $\mathrm{N}$, reducing the depth of indenter penetrating and making it

\footnotetext{
* SILESIAN UNIVERSITY OF TECHNOLOGY, INSTITUTE OF ENGINEERING MATERIALS AND BIOMATERIALS, 18 A KONARSKIEGO STR., 44-100 GLIWICE, POLAND

" Corresponding author: ludwina.zukowska@polsl.pl
} 
possible to minimalize the influence of the substrate material on the measurement results. Further reduction of maximum load caused significmant decrease of measurement precision.

Adhesion evaluation of the coatings on the investigated inserts was made using the scratch test on the CSEM REVETEST device, by moving the diamond penetrator along the examined specimen's surface with the gradually increasing load. The critical load values Lc (AE) were determined using the scratch method with the linearly increasing load ("scratch test"), characterising adhesion of the investigated PVD coatings onto the substrate. The critical load was determined as the one corresponding to the acoustic emission increase signalling beginning of spalling of the coating.

Cutting ability of the investigated materials was determined basing on the technological continuous cutting tests of the EN-GJL-250 grey cast iron with the minimal strength $\mathrm{Rm}$ of $250 \mathrm{MPa}$ and hardness of about $210 \mathrm{HB}$. The $\mathrm{VB}=0.20 \mathrm{~mm}$ width of the wear band on the surface of the tool used for machining was the criterion of the cutting edge consumption evaluation. The following parameters were used in the machining capability experiments: feed rate $\mathrm{f}=0.1 \mathrm{~mm} /$ trn, depth of cut ap=1 mm, cutting speed $\mathrm{vc}=150 \mathrm{~m} / \mathrm{min}$.

The model whereof objective is to determine the internal stresses in gradient and single-layer coatings $(\mathrm{Ti}, \mathrm{Al}) \mathrm{N}$ on the substrate from cemented carbides, cermets and oxide tool ceramics, was elaborated using the finite elements method, assuming true dimensions of the specimen. The geometry of the insert with the deposited gradient and single-layer coatings as well as the calculations were carried out using the ANSYS 12 software. On account of the predicted simulation range, parametric calculation files were elaborated which allowed to perform the analysis in a comprehensive way. The geometrical model was subjected to discretization with the element of the PLANE 42 type for substrate material and external coating. The calculation model consists of 12816 nodes and 11780 elements. In order to avoid errors in the calculation of internal stresses in the coatings, we applied variable quantities of finite elements. In the places where higher gradients of stresses were expected, the network is more condensed than in the areas where the stresses were expected to have values similar to one another. Therefore, in the coatings we applied smaller elements which better reflect the gradients of stresses, and in the substrate material the elements are increasing with the rise of the distance from the coatings. Figure 1 presents the real model of gradient and single- layer coatings.

Since it was necessary to calculate internal stresses in the material of the chemical composition which was changing in the way perpendicular to the surface, the ideographic differentiation of the modeled gradient coatings was carried out into zones corresponding to the areas of similar chemical composition. The model with the spherical division of gradient coating was elaborated in the way ensuring that it was possible to determine the averaged internal stresses in the coating areas important in view of the applicability properties and to compare the obtained results with the calculations carried out for homogeneous coatings.

The following boundary conditions were accepted to simulate the eigen-stresses in the gradient single-layer (Ti,Al) $\mathrm{N}$ coatings on different substrates:

- the temperature change of the PVD process is reflected by cooling the specimen from $500^{\circ} \mathrm{C}$ to the ambient temperature of $20^{\circ} \mathrm{C}$,

- $\quad$ for the coatings $(\mathrm{Ti}, \mathrm{Al}) \mathrm{N}$ for the substrate from cemented carbides, cermets and oxide tool ceramics, the material properties were accepted basing on literature data [1-6] and MatWeb catalogue.

The discrepancies in literature data involving the values of physical properties of particular materials result from different acquisition methods, from the differences in the structure and composition of the materials and from errors in the applied measurement method, the substrate of the investigated specimen is immobilized due to depriving all nodes lying on this axis of all degrees of freedom.

With the temperature drop, from the coating deposition temperature $\left(500^{\circ} \mathrm{C}\right)$ to the ambient temperature $\left(20^{\circ} \mathrm{C}\right)$, internal stresses are generated both in the coating and in the substrate material, connected principally with different thermal expansion of particular materials. The distribution of these stresses is also connected with the geometry of the specimen and with thermal transfer during the cooling process. In effect of non-uniform cooling of the specimen material in

TABLE 1

Characteristics of the investigated materials

\begin{tabular}{|c|c|c|c|c|c|c|}
\hline Substrate & Coating & $\begin{array}{c}\text { Coating thickness, } \\
\mu \mathrm{m}\end{array}$ & $\begin{array}{c}\text { Roughness, } \\
\text { Ra, } \mu \mathrm{m}\end{array}$ & $\begin{array}{c}\text { Microhardnes, } \\
\text { HV }\end{array}$ & $\begin{array}{l}\text { Critical Load, } \\
\text { Lc, N }\end{array}$ & $\begin{array}{c}\text { Tool life } \\
\text { t, min }\end{array}$ \\
\hline \multirow{3}{*}{$\begin{array}{l}\text { Cemented } \\
\text { carbide* }\end{array}$} & uncoated & - & 0.13 & 1755 & - & 2.5 \\
\hline & $(\mathrm{Ti}, \mathrm{Al}) \mathrm{N}$ & 2.2 & 0.14 & 2750 & 52 & 20.0 \\
\hline & gradient $(\mathrm{Ti}, \mathrm{Al}) \mathrm{N}$ & 2.6 & 0.14 & 3000 & 56 & 25.5 \\
\hline \multirow{3}{*}{ Cermet** } & uncoated & - & 0.06 & 1850 & - & 2.5 \\
\hline & $(\mathrm{Ti}, \mathrm{Al}) \mathrm{N}$ & 1.5 & 0.13 & 2900 & 54 & 19.5 \\
\hline & gradient $(\mathrm{Ti}, \mathrm{Al}) \mathrm{N}$ & 3.0 & 0.12 & 3150 & 63 & 22.0 \\
\hline \multirow{3}{*}{$\mathrm{Al}_{2} \mathrm{O}_{3}+\mathrm{TiC}^{* * *}$} & uncoated & - & 0.10 & 2105 & - & 12.5 \\
\hline & $(\mathrm{Ti}, \mathrm{Al}) \mathrm{N}$ & 1.6 & 0.27 & 3170 & 53 & 21.0 \\
\hline & gradient $(\mathrm{Ti}, \mathrm{Al}) \mathrm{N}$ & 3.2 & 0.24 & 3200 & 65 & 40.0 \\
\hline
\end{tabular}

\footnotetext{
* phase composition: WC, TiC, TaC, Co; ** phase composition: TiCN, WC, TiC, TaC, $\mathrm{Co}, \mathrm{Ni}$; *** phase composition: $\mathrm{Al}_{2} \mathrm{O}_{3}, \mathrm{TiC}^{2}$
} 
the particular areas, the distribution of stresses on the coating surface and their concentration in the corners of the specimen is different.

To verify the results of computer simulation, the values of internal stresses in the investigated single-layer and gradient coatings were calculated using the X-ray $\sin 2 \psi$ technique.
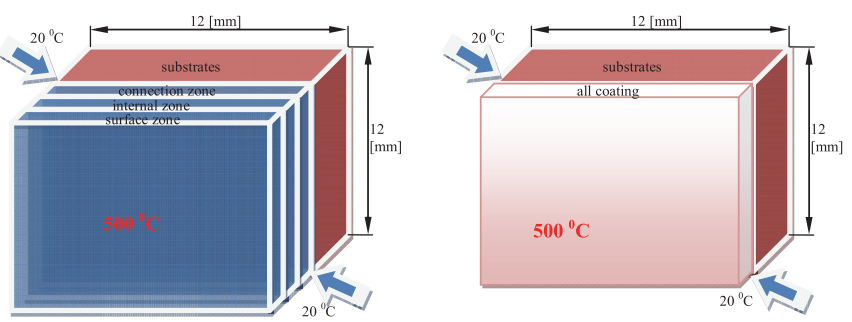

Fig. 1. Real model of gradient and single-layer coatings

TABLE 2

Properties of individual materials

\begin{tabular}{|c|c|c|c|c|}
\hline \multirow[b]{2}{*}{ Substrate } & \multirow[b]{2}{*}{$\begin{array}{l}\text { Coating } \\
\text { zone }\end{array}$} & \multicolumn{3}{|c|}{ Physical properties } \\
\hline & & $\begin{array}{c}\text { Young's } \\
\text { modulus, } \\
{[\mathrm{GPa}]}\end{array}$ & $\begin{array}{c}\text { Thermal } \\
\text { expansion } \\
\text { coefficient, } \\
{[10-6 \cdot \mathrm{K}-1]}\end{array}$ & $\begin{array}{c}\text { Poisson } \\
\text { ratio }\end{array}$ \\
\hline \multirow{3}{*}{$\begin{array}{l}(\mathrm{Ti}, \mathrm{Al}) \mathrm{N} \\
\text { gradient }\end{array}$} & $\begin{array}{c}\text { Surface } \\
\text { zone }\end{array}$ & 420 & 6.1 & 0.23 \\
\hline & $\begin{array}{c}\text { Internal } \\
\text { zone }\end{array}$ & 480 & 7.1 & 0.21 \\
\hline & $\begin{array}{c}\text { Connection } \\
\text { zone }\end{array}$ & 510 & 8.5 & 0.26 \\
\hline$(\mathrm{Ti}, \mathrm{Al}) \mathrm{N}$ & - & 480 & 7.1 & 0.21 \\
\hline $\begin{array}{l}\text { Cemented } \\
\text { carbides }\end{array}$ & - & 500 & 7.9 & 0.22 \\
\hline Cermet & - & 450 & 9.0 & 0.22 \\
\hline $\mathrm{Al}_{2} \mathrm{O}_{3}+\mathrm{TiC}$ & - & 400 & 8.0 & 0.21 \\
\hline
\end{tabular}

TABLE 3

Results of computer simulation of internal stresses in the analysed gradient PVD coatings

\begin{tabular}{|c|c|c|c|c|}
\hline \hline \multirow{2}{*}{ Substrate } & \multirow{2}{*}{ Coating } & \multicolumn{3}{|c|}{ Computer simulation results of internal } \\
\cline { 3 - 5 } & & $\begin{array}{c}\text { Surface } \\
\text { layer }\end{array}$ & $\begin{array}{c}\text { Middle } \\
\text { layer }\end{array}$ & $\begin{array}{c}\text { Contact } \\
\text { area }\end{array}$ \\
\hline $\begin{array}{c}\text { Cemented } \\
\text { carbide }\end{array}$ & $(\mathrm{Ti}, \mathrm{Al}) \mathrm{N}$ & -350 & -220 & 130 \\
\hline $\mathrm{Cermet}$ & $(\mathrm{Ti}, \mathrm{Al}) \mathrm{N}$ & -570 & -350 & -100 \\
\hline $\mathrm{Al}_{2} \mathrm{O}_{3}+\mathrm{TiC}$ & $(\mathrm{Ti}, \mathrm{Al}) \mathrm{N}$ & -380 & -250 & 100 \\
\hline
\end{tabular}

TABLE 4

Results of computer simulation of internal stresses in the analysed single-layer PVD coatings

\begin{tabular}{|c|c|c|}
\hline \hline Substrate & Coating & $\begin{array}{c}\text { Computer simulation results of } \\
\text { internal stress, [MPa] }\end{array}$ \\
\hline $\begin{array}{c}\text { Cemented } \\
\text { carbide }\end{array}$ & $(\mathrm{Ti}, \mathrm{Al}) \mathrm{N}$ & 170 \\
\hline Cermet & $(\mathrm{Ti}, \mathrm{Al}) \mathrm{N}$ & -410 \\
\hline $\mathrm{Al}_{2} \mathrm{O}_{3}+\mathrm{TiC}$ & $(\mathrm{Ti}, \mathrm{Al}) \mathrm{N}$ & -180 \\
\hline
\end{tabular}

TABLE 5

Results of experimental internal stresses using the X-ray $\sin ^{2} \psi$ technique of the analysed PVD coatings

\begin{tabular}{|c|c|c|}
\hline \hline \multirow{2}{*}{ Substate } & Coating & $\begin{array}{c}\text { Internal stresses } \\
\sigma[\mathrm{MPa}]\end{array}$ \\
\hline \multirow{3}{*}{ Cemented carbide } & $(\mathrm{Ti}, \mathrm{Al}) \mathrm{N}$ & $212 \pm 42$ \\
\cline { 2 - 3 } & $(\mathrm{Ti}, \mathrm{Al}) \mathrm{N}$ gradient & $-395 \pm 45$ \\
\hline \multirow{2}{*}{ Cermet } & $(\mathrm{Ti}, \mathrm{Al}) \mathrm{N}$ & $-459 \pm 49$ \\
\cline { 2 - 3 } & $(\mathrm{Ti}, \mathrm{Al}) \mathrm{N}$ gradient & $-647 \pm 77$ \\
\hline \multirow{2}{*}{$\mathrm{Al}_{2} \mathrm{O}_{3}+\mathrm{TiC}$} & $(\mathrm{Ti}, \mathrm{Al}) \mathrm{N}$ & $-228 \pm 48$ \\
\cline { 2 - 3 } & $(\mathrm{Ti}, \mathrm{Al}) \mathrm{N}$ gradient & $-456 \pm 76$ \\
\hline
\end{tabular}

\section{Results}

The deposition of single-layer and gradient (Ti,Al) $\mathrm{N}$ wear-resistant coatings on the investigated sintered tool materials results in the rise of roughness parameter $R_{a}$ which is within the range from $0.12 \div 0.27 \mu \mathrm{m}$ (Table 1 ).

The deposited PVD coatings are characterized by good adhesion to the substrate within the range $\mathrm{L}_{\mathrm{c}}=52 \div 65 \mathrm{~N}$. In general, the deposition of wear resistant gradient $(\mathrm{Ti}, \mathrm{Al}) \mathrm{N}$ coatings on the investigated sintered tool materials results in a considerable rise of microhardness in the area around the surface, which, combined with the good adhesion of the coating to the substrate obtained in effect of the application of gradient structure of the coating, yields good functionality properties of these materials, confirmed during machining tests (Table 1).

The hardness of the substrate material (Table 1) is 1755 $\mathrm{HV}$ for cemented carbides, $1850 \mathrm{HV}$ for cermet and $2105 \mathrm{HV}$ for oxide ceramics. The deposition of the (Ti,Al)N coatings on the investigated sintered tool materials results in a considerable rise of microhardness in the area around the surface within the range of $2600 \div 3200 \mathrm{HV}$. It was demonstrated that the gradient coatings have higher hardness than the single-layer coatings, independent of the substrate material. In case of single-layer (Ti,Al)N coatings deposited on cemented carbides, the tensile stresses has been stated, while in case of cermets and sintered oxide ceramic substrates, the compressive stresses occurred. The range of measured stresses occurred in single-layer (Ti,Al) $\mathrm{N}$, depending on substrate used was $580 \mathrm{MPa}$.

As the result of performed simulation it was observed, that for all used types of substrates, the replacement of single layer $(\mathrm{Ti}, \mathrm{Al}) \mathrm{N}$ coatings by gradient $(\mathrm{Ti}, \mathrm{Al}) \mathrm{N}$ coating, takes effect on significant reduction of absolute value of stresses in the connection zone (Tables 3, 4).

Reduction of internal stresses' absolute values in the connection zone of the gradient coatings with the substrate takes profitably effects on improvement of coatings adhesion. Too high compressive stresses' value can be a reason of too high tensile stresses ocurring under the coating reducing fatigue resistance of the element. Increase of gradient coatings adhesion in comparison with adhesion of single-layer coatings was confirmed as a result of "scratch tests" done and may be one of main factors making influence on much better wear resistance results obtained during machining tests in comparison to single-layer coatings. (Table 1). 
It was found that thanks to use of gradient coating in all examined substrates, compressive stresses in surface layer of coating were obtained. Moreover, increase of compressive stress' values on the surface of gradient coatings in comparison to single-layer coatings was observed (Table 3, 4, Fig. 2). Occurrence of 350-570 MPa values of compressive stresses, on the surface of gradient coatings has advantageous influence on their mechanical properties, especially on microhardness what was confirmed as a result of microhardness measurements.

Due to the application of gradient coatings on all investigated substrate materials, we obtained compressive stresses in the surface layer of the coating having a direct contact with the machined material during the operation process (Table 3 ). The generation of compressive stresses in the surface layer brings about better resistance to cracking, and through the rise of hardness, improves the resistance to wear. The generation of compressive stresses in the surface layer can prevent the formation of cracks when the element in the operational conditions is subjected to stresses generated by external forces. Yet, an excessive value of compressive stresses can lead to adhesive wear and can bring about the formation of too high tensile stresses under the coating, lowering the fatigue resistance of the element [1-6]. Relation between the value of stresses and the hardness of the layer of titanium nitrides obtained in effect of magnetron sputtering, demonstrating that with the rise of compressive stresses the hardness of the obtained layer is progressively increasing [11]. Basing on the carried out research, it was demonstrated that the occurrence of compressive stresses on the surface of gradient coatings of the investigated materials has a positive influence on their mechanical properties, in particular on the microhardness (Table 1).

To verify the results of computer simulation, the values of eigen-stresses in the investigated single-layer and gradient coatings were calculated using the X-ray $\sin 2 \psi$ technique. There was stated high level compatibility of FEM modelled stresses with the stresses measured using the X-ray $\sin 2 \psi$ technique (Table 5). a)

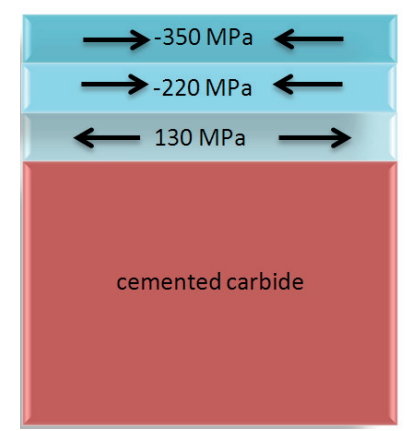

b)

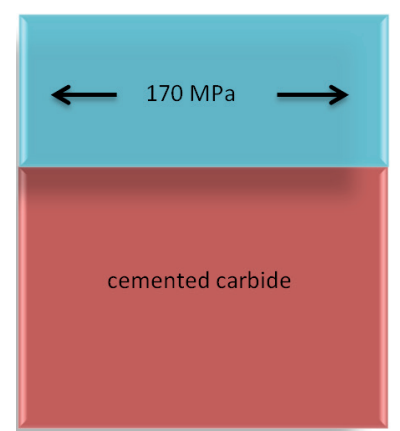

Fig. 2. Schematic distribution of stresses in the a) gradient (Ti,Al)N b) single-layer coating deposited on cemented carbides obtained by computer simulation

\section{Conclusions}

The results of the computer simulation with the use of finite element method (FEM) for determining the internal stresses of gradient and single-layer coatings $(\mathrm{Ti}, \mathrm{Al}) \mathrm{N}$ and $\mathrm{Ti}(\mathrm{C}, \mathrm{N})$ deposited on the sintered tool materials, including cemented carbides, cermets and $\mathrm{Al}_{2} \mathrm{O}_{3}+\mathrm{TiC}$ type oxide tool ceramics by cathodic arc evaporation CAE-PVD method are given in the paper.

Many aspects pertaining to forming of coatings, including also the process conditions effect on their properties, still remain inexplicable in spite of the enormous interest paid in them by many industrial centres and research laboratories.

Developing an appropriate model allows the prediction of properties of PVD coatings, which are also the criterion of their selection for specific items, based on the parameters of technological processes. In addition, developed model can to a large extent eliminate the need for expensive and timeconsuming experimental studies for the computer simulation.

A more advantageous distribution of stresses in gradient coatings than in respective single-layer coatings yields better mechanical properties, and, in particular, the distribution of stresses on the coating surface has the influence on microhardness, and the distribution of stresses in the contact area between the coating and substrate has the influence on the adhesion of coatings.

\section{REFERENCES}

[1] L.A. Dobrzański, A. Śliwa, W. Sitek, Surf. Eng. 5, Seattle (2006).

[2] L.A. Dobrzański, M. Staszuk, K. Gołombek, A. Śliwa, M. Pancielejko, Arch. Metall., Mat. 55, 187 (2010).

[3] L.A. Dobrzański, W. Kwaśny, B. Dołżańska, A. Śliwa , K. Gołombek, G. Nowak, Arch. Mater. Sci. Eng. 57, 38 (2012).

[4] Ł. Szparaga, J. Ratajski, Adv. Mater. Sci. Eng. 14, 5 (2014).

[5] A. Śliwa, T. Tański, R. Dziwis, W. Kwaśny, M. Pancielejko, Arch. Mater. Sci. Eng. 64, 28 (2013).

[6] A. Śliwa, W. Kwaśny, L.A. Dobrzański, R. Dziwis, Arch. Mater. Sci. Eng. 63, 68 (2013).

[7] L.A. Dobrzański, L.W. Żukowska, J. Mikuła , K. Gołombek, D. Pakuła, M. Pancielejko, J. Mat. Proc. Tech. 201, 310 (2008).

[8] K. Lukaszkowicz, A. Czyzniewski, W. Kwasny, M. Pancielejko, Vac. 86, 1186 (2012).

[9] L.A. Dobrzański, D. Pakula, J. Mikula, K. Golombek, Inter. J. Surf. Sci. Eng. 1, 111 (2012).

[10] L.A. Dobrzański, J. Mikuła, K. Gołombek, Mater. Sci. Forum, 530-531, 499 (2006).

[11] [11] V. Valvoda, J. Alloys Compd 219, 83 (1995).

[12] [12] M. Staszuk, L.A. Dobrzański, T. Tański, W. Kwaśny, M. Musztyfaga-Staszuk, Arch. Metall., Mat. 59, 269 269-274 (2014).

[13] [13]L. Żukowska, J. Mikuła, M. Staszuk, M. MusztyfagaStaszuk, Arch. Metall. Mat. 2, (2015) (in press). 